Article

\title{
Bifunctional palladium composite membrane for hydrogen separation and catalytic CO methanation
}

\author{
Xiaojuan Hu, Wenjun Yan, Weihua Ding, Jian Yu, Yan Huang* \\ State Key Laboratory of Materials-Oriented Chemical Engineering, College of Chemistry and Chemical Engineering, Nanjing University of Technology, \\ Nanjing 210009, Jiangsu, China
}

\section{A R T I C L E I N F O}

\section{Article history:}

Received 30 April 2013

Accepted 17 June 2013

Published 20 September 2013

Keywords:

Palladium membrane

Hydrogen separation

Carbon monoxide methanation

Bifunction

Nickel catalyst

Proton exchange membrane fuel cell

\begin{abstract}
A B S T R A C T
$\mathrm{NiO}$ was introduced into the porous $\mathrm{Al}_{2} \mathrm{O}_{3}$ substrate by impregnation, and the resulting $\mathrm{NiO} / \mathrm{Al}_{2} \mathrm{O}_{3}$ was coated with the lead of a $2 \mathrm{~B}$ pencil to modify its surface. A palladium layer with a thickness of 5 $\mu \mathrm{m}$ was deposited by electroless plating on the Pencil/NiO/ $/ \mathrm{Al}_{2} \mathrm{O}_{3}$ substrate, and a $\mathrm{Pd} / \mathrm{Pencil} / \mathrm{Ni} /$ $\mathrm{Al}_{2} \mathrm{O}_{3}$ membrane was obtained after reduction with hydrogen. For reference, a Ni-free Pd/Pencil/ $\mathrm{Al}_{2} \mathrm{O}_{3}$ membrane was also fabricated. The surface and cross-sectional morphologies of the membranes were studied by scanning electron microscopy and metallographic microscopy. The hydrogen permeation kinetics was investigated by single gas tests, and the hydrogen separation performances of the $\mathrm{Pd} / \mathrm{Pencil} / \mathrm{Al}_{2} \mathrm{O}_{3}$ and $\mathrm{Pd} / \mathrm{Pencil} / \mathrm{NiO} / \mathrm{Al}_{2} \mathrm{O}_{3}$ membranes were tested with a hydrogen feed composed of $\mathrm{H}_{2} 77.8 \%$, $\mathrm{CO} 5.2 \%, \mathrm{CO}_{2} 13.5 \%$, and $\mathrm{CH}_{4} 3.5 \%$. The Ni-free Pd/Pencil/ $\mathrm{Al}_{2} \mathrm{O}_{3}$ membrane only shows function of hydrogen separation, while the $\mathrm{Pd} / \mathrm{Pencil} / \mathrm{Ni} / \mathrm{Al}_{2} \mathrm{O}_{3}$ is also catalytically effective for methanation of $\mathrm{CO}$ and $\mathrm{CO}_{2}$ in hydrogen, forming a bifunctional palladium membrane concept. Since the amount of $\mathrm{CO}$ and $\mathrm{CO}_{2}$ in the hydrogen after membrane separation is very low, the consumption of hydrogen by the methanation reactions is negligible. The bifunctional membrane is promising for proton exchange membrane fuel cells because the catalytic methanation treatment solves the CO poisoning problem of the fuel cell electrodes and consequently allows the palladium membrane to tolerate more membrane defects and to achieve longer life.
\end{abstract}

(C) 2013, Dalian Institute of Chemical Physics, Chinese Academy of Sciences. Published by Elsevier B.V. All rights reserved.

\section{Introduction}

Being different from the hydrogen production for industrial applications, that for hydrogen energy utilizations places a high demand on the miniaturization and portability of the hydrogen generation system, and a key unit of which is the hydrogen separator. Among various hydrogen separation processes, the membrane technology is of great advantage. Proton exchange membrane (PEM) fuel cells are the most common hydrogen-fueled ones [1,2]. Their anode contains a platinum catalyst, which is able to oxidize hydrogen to water at room tempera- ture and release the electric power, but this catalyst requires a very high purity of hydrogen. Currently, most of the hydrogen is produced by steam reforming of fossil fuels, and it unavoidably contains a small amount of CO. Since CO can easily poison the platinum catalyst of the PEM fuel cell anode, the CO content in the hydrogen fuel has to be controlled to below $0.001 \%[3,4]$, and this is highly challenging for the membrane selectivity. A number of hydrogen separation membranes have been reported, but palladium and palladium-alloy membranes are preferred because they have high hydrogen permeability and the best permselectivity and can reject any other gas. On the

\footnotetext{
*Corresponding author. Tel: +86-25-83172253; E-mail: huangy@njut.edu.cn This work was supported by the Natural Science Foundation of the Higher Education Institutions of Jiangsu Province, China (09KJA530003), the China Postdoctoral Science Foundation (2011M501220), and the Jiangsu Planned Projects for Postdoctoral Research Fund (1102090C). DOI: 10.1016/S1872-2067(12)60636-6 | http://www.sciencedirect.com/science/journal/18722067 | Chin. J. Catal., Vol. 34, No. 9, September 2013
} 
other hand, it is of great interest to eliminate the CO in the hydrogen fuel. Apart from the membrane technology [5,6], catalytic oxidation $[7,8]$ or methanation of $\mathrm{CO}[9,10]$ can be an alternative. The catalytic oxidation route needs the introduction of appropriate amount of oxygen and should convert $\mathrm{CO}$ to $\mathrm{CO}_{2}$ without the oxidation of hydrogen, and the catalyst selectivity is of key importance. Catalytic methanation converts $\mathrm{CO}$ into $\mathrm{CH}_{4}$ through catalytic hydrogenation. In addition to $\mathrm{CO}$, the industrial hydrogen often contains $\mathrm{CO}_{2}$, which can also be converted during methanation. Since the methanation of each mole of $\mathrm{CO}$ or $\mathrm{CO}_{2}$ will need 3 or $4 \mathrm{~mol}$ hydrogen, this process is not applicable for the hydrogen feed with a high amount of $\mathrm{CO}$ and $\mathrm{CO}_{2}$.

Commercial palladium alloy membranes are fabricated by cold rolling, and their thickness can be as thick as $50 \mu \mathrm{m}$ or higher. Their disadvantages such as high cost, low hydrogen permeance, and poor mechanical strength greatly limited their applications. A significant improvement can be achieved by the use of composite membranes, i.e., very thin membranes supported on porous materials, and they can be one order of magnitude thinner than the conventional ones. However, the stability of composite Pd membranes is the key factor that limits their industrial applications. During long term membrane operation, pinholes will gradually appear and lead to a decrease in hydrogen purity. Once the CO concentration exceeds the level acceptable for the PEM fuel cells, the life of the Pd membranes is over. Since the PEM fuel cells are so sensitive to CO, the lifetime of the composite Pd membranes eventually becomes a key problem. Based on the characteristics of the methanation and membrane separation approaches, we invented a kind of bifunctional membranes [11], i.e., the Pd membranes with a $\mathrm{Ni}$ catalyst supported on their porous substrate material, so that both functions of hydrogen separation and CO methanation are integrated. On one hand, the catalytic methanation eases the strict requirement on the CO leakage through the Pd membranes and equivalently prolongs the membrane life. On the other hand, the contents of $\mathrm{CO}$ and $\mathrm{CO}_{2}$ in the hydrogen after membrane separation are extremely low, and the hydrogen consumption will be negligible if the methanation is conducted thereafter.

In this work, a bifunctional $\mathrm{Pd} / \mathrm{Pencil} / \mathrm{Ni} / \mathrm{Al}_{2} \mathrm{O}_{3}$ membrane with the functions of hydrogen separation and $\mathrm{CO}$ methanation was prepared, and its hydrogen separation performance was compared with that of the Ni-free $\mathrm{Pd} / \mathrm{Pencil} / \mathrm{Al}_{2} \mathrm{O}_{3}$ membrane.

\section{Experimental}

\subsection{Membrane preparation}

\subsection{1. $\mathrm{NiO}$ deposition on $\mathrm{Al}_{2} \mathrm{O}_{3}$ substrate}

Conventional porous $\mathrm{Al}_{2} \mathrm{O}_{3}$ ceramic tubes (o.d., $13 \mathrm{~mm}$; i.d., 8 $\mathrm{mm}$; length, $75 \mathrm{~mm}$ ) with a symmetric structure were employed as the substrate material. They were cleaned with a hot solution of a commercial detergent, rinsed repeatedly with deionized water, and finally dried at $120{ }^{\circ} \mathrm{C}$ overnight.

$\mathrm{NiO} / \mathrm{Al}_{2} \mathrm{O}_{3}$ was prepared by impregnation. The $\mathrm{Al}_{2} \mathrm{O}_{3}$ substrate was immersed in a $\mathrm{Ni}\left(\mathrm{NO}_{3}\right)_{2}$ solution $(0.25 \mathrm{~mol} / \mathrm{L})$ for 10 $\mathrm{h}$, then dried at $120^{\circ} \mathrm{C}$ for $12 \mathrm{~h}$, and finally calcined at $450{ }^{\circ} \mathrm{C}$ for $3 \mathrm{~h}$. The NiO content as measured by weight gain was $3.6 \%$, which amounts to a nickel content of $2.8 \%$.

\subsubsection{Substrate surface modification}

The $\mathrm{Al}_{2} \mathrm{O}_{3}$ and $\mathrm{NiO} / \mathrm{Al}_{2} \mathrm{O}_{3}$ surfaces were modified by means of pencil coating $[12,13]$, which was carried out by scraping with a conventional $2 \mathrm{~B}$ pencil so that a uniform and continuous coating layer can be created. The modified substrates were calcined at $450{ }^{\circ} \mathrm{C}$ for $3 \mathrm{~h}$ to burn off oil contaminants, resulting Pencil $/ \mathrm{Al}_{2} \mathrm{O}_{3}$ and Pencil/NiO/ $/ \mathrm{Al}_{2} \mathrm{O}_{3}$.

\subsubsection{Electroless plating [14]}

Before plating, the Pencil $/ \mathrm{Al}_{2} \mathrm{O}_{3}$ and Pencil/NiO/ $/ \mathrm{Al}_{2} \mathrm{O}_{3}$ were activated with the $\mathrm{SnCl}_{2} / \mathrm{PdCl}_{2}$ method. The sensitization and activation reagents were composed of $5 \mathrm{~g} / \mathrm{L} \mathrm{SnCl}_{2}$ and $0.2 \mathrm{~g} / \mathrm{L}$ $\mathrm{PdCl}_{2}$, respectively, and both of regents also contain $1 \mathrm{ml} / \mathrm{L}$ concentrated $\mathrm{HCl}$. The electroless plating was carried out at 30 ${ }^{\circ} \mathrm{C}$. The plating bath was composed of $5 \mathrm{~g} / \mathrm{L} \mathrm{PdCl}_{2}, 70 \mathrm{~g} / \mathrm{L}$ $\mathrm{Na}_{2}$ EDTA, and $250 \mathrm{~mL} / \mathrm{L} \mathrm{NH}_{3} \cdot \mathrm{H}_{2} \mathrm{O}$ (28\%), and the reducing agent was a hydrazine solution $(0.2 \mathrm{~mol} / \mathrm{L})$. The thickness of the Pd membranes was controlled by the volume of the plating bath, and it would be $5 \mu \mathrm{m}$ if there was no loss of palladium.

\subsection{Characterization and permeation tests}

The pore size of the $\mathrm{Al}_{2} \mathrm{O}_{3}$ substrate was measured with a porometer (GaoQ PSDA-20) through a bubble-point (also known as gas-liquid displacement or capillary flow) method [15]. The surface morphology was studied by scanning electron microscopy (SEM, FEI Quanta-200). The cross-section of the Pd membranes was observed with a metallographic microscope (Leica DM-4000M), but the specimen were encapsulated with epoxy resin and pretreated on a grinder-polisher (Buehler Phenix Beta) before analysis.

The palladium membrane was assembled in a module (GaoQ PM-201S). The permeation kinetics was studied by the single gas method, and the practical hydrogen separation performance was tested with a gas mixture $\left(\mathrm{H}_{2} 77.8 \%\right.$, CO $5.2 \%$, $\mathrm{CO}_{2} 13.5 \%$, and $\mathrm{CH}_{4} 3.5 \%$ ). The pressure at the shell side of the membrane was controllable, while the pressure at the tube side of the membrane was always ambient. During testing, the $\mathrm{NiO}$ supported on the $\mathrm{Al}_{2} \mathrm{O}_{3}$ substrate was reduced in situ into the metallic nickel catalyst. The permeated hydrogen was analyzed with an online gas chromatograph (Shimadzu-2014).

\section{Results and discussion}

\subsection{Membrane morphology}

Porous $\mathrm{Al}_{2} \mathrm{O}_{3}$ is the most common substrate material for palladium membranes, but in this work it was also used as a support of the methanation catalyst. The porometry results indicate that the largest and the average pore sizes of the porous $\mathrm{Al}_{2} \mathrm{O}_{3}$ substrate are 1.5 and $3.7 \mu \mathrm{m}$, respectively. As reported in the literature, the substrate materials for Pd membranes often have an average pore size below $0.2 \mu \mathrm{m}$, and they 


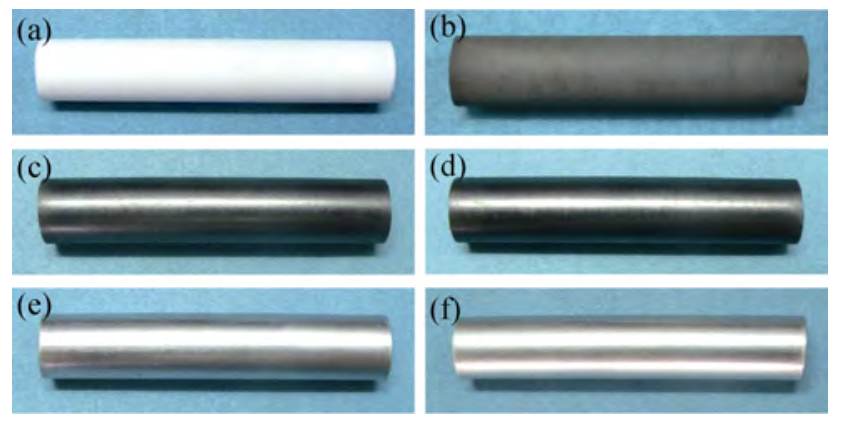

Fig. 1. Photos of the fresh porous $\mathrm{Al}_{2} \mathrm{O}_{3}$ substrate (a), $\mathrm{NiO} / \mathrm{Al}_{2} \mathrm{O}_{3}$ (b), Pencil/ $/ \mathrm{Al}_{2} \mathrm{O}_{3}$ (c), Pencil/NiO $/ \mathrm{Al}_{2} \mathrm{O}_{3}$ (d), Pd/Pencil/ $/ \mathrm{Al}_{2} \mathrm{O}_{3}$ (e), and $\mathrm{Pd} / \mathrm{Pencil} / \mathrm{NiO} / \mathrm{Al}_{2} \mathrm{O}_{3}(\mathrm{f})$.

have an asymmetric structure in order to control the pore size and the diffusion resistance, leading to a very high cost. This work chose a low-cost macroporous $\mathrm{Al}_{2} \mathrm{O}_{3}$ as the substrate material so as to reduce the whole membrane cost and promote the membrane commercialization. The photos of the substrate materials and membranes are displayed in Fig. 1. The $\mathrm{Al}_{2} \mathrm{O}_{3}$ substrate surface was rough, and the $\mathrm{NiO} / \mathrm{Al}_{2} \mathrm{O}_{3}$ surface is black and uniform. The Pencil/ $/ \mathrm{Al}_{2} \mathrm{O}_{3}$ and Pencil/NiO/ $/ \mathrm{Al}_{2} \mathrm{O}_{3}$ are lustrous and show typical graphite color. In fact, the pencil coating process has been developed specially by our group for the surface modification of the macroporous substrate materials. It is simple, low cost, and environmental benign. The $\mathrm{Pd} / \mathrm{Pencil} / \mathrm{Al}_{2} \mathrm{O}_{3}$ and $\mathrm{Pd} / \mathrm{Pencil} / \mathrm{NiO} / \mathrm{Al}_{2} \mathrm{O}_{3}$ membranes prepared in this work look lustrous and homogeneous.

The surface views are demonstrated in Fig. 2. The $\mathrm{Al}_{2} \mathrm{O}_{3}$ substrate is composed of the sintered irregular ceramic particles, while the $\mathrm{NiO} / \mathrm{Al}_{2} \mathrm{O}_{3}$ surface shows a very different morphology because a layer of fine particles appears, and this is obviously caused by the deposition of NiO. The Pencil/ $/ \mathrm{Al}_{2} \mathrm{O}_{3}$ and Pencil/NiO/ $/ \mathrm{Al}_{2} \mathrm{O}_{3}$ have low surface roughness and almost the same morphology, and so do the $\mathrm{Pd} / \mathrm{Pencil} / \mathrm{Al}_{2} \mathrm{O}_{3}$ and $\mathrm{Pd} / \mathrm{Pencil} / \mathrm{NiO} / \mathrm{Al}_{2} \mathrm{O}_{3}$ membranes, indicating no significant influence of the $\mathrm{NiO}$ deposition on the membrane preparation. The cross-sectional metallographic photomicrographs of the $\mathrm{Pd} / \mathrm{Pencil} / \mathrm{Al}_{2} \mathrm{O}_{3}$ and $\mathrm{Pd} / \mathrm{Pencil} / \mathrm{NiO} / \mathrm{Al}_{2} \mathrm{O}_{3}$ membranes are shown in Fig. 3. After grinding and polishing, the Pd layer became highly bright and can be clearly observed with microscope. The cross-sectional morphologies of the two palladium membranes are similar, and the Pd layers are uniform and bonded well onto the substrates. During membrane preparation, the membrane thickness has been controlled to be $5 \mu \mathrm{m}$ through the volume of the plating bath. As confirmed by Fig. 3, the thicknesses of the two membranes are indeed close to 5 $\mu \mathrm{m}$, indicating that the palladium ions in the plating bath have been sufficiently transferred. During electroless plating, excess hydrazine has been added before every plating bath renewing so that the remnant palladium ions can be fully reduced and the loss of the precious palladium can be avoided.

\subsection{Hydrogen permeation kinetics}

The permeation kinetics of the Pd membranes was analyzed with the $\mathrm{H}_{2} / \mathrm{N}_{2}$ single gas method [14], and the testing temper-
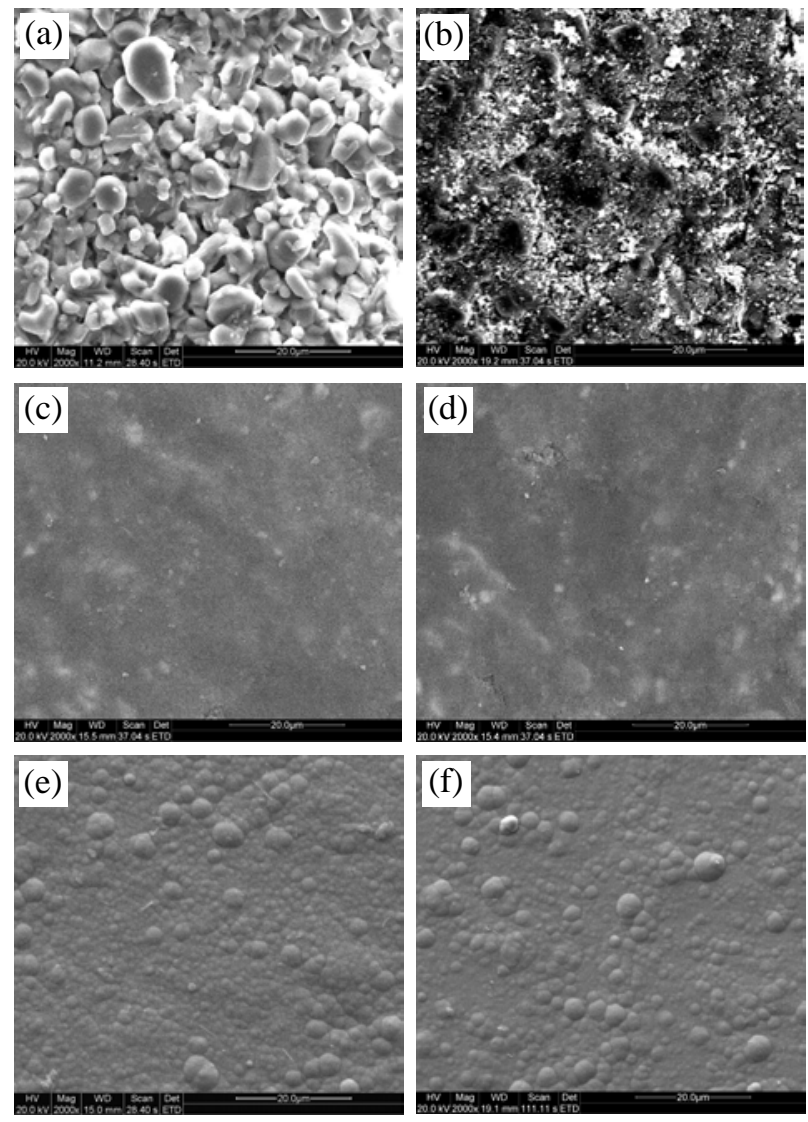

Fig. 2. $\mathrm{SEM}$ micrographs of the fresh $\mathrm{Al}_{2} \mathrm{O}_{3}$ substrate (a), $\mathrm{NiO} / \mathrm{Al}_{2} \mathrm{O}_{3}$ (b), Pencil $/ \mathrm{Al}_{2} \mathrm{O}_{3}$ (c), Pencil/NiO/ $/ \mathrm{Al}_{2} \mathrm{O}_{3}$ (d), Pd/Pencil/ $/ \mathrm{Al}_{2} \mathrm{O}_{3}$ (e), and $\mathrm{Pd} / \mathrm{Pencil} / \mathrm{NiO} / \mathrm{Al}_{2} \mathrm{O}_{3}$ (f).

atures were 350,400 , and $450{ }^{\circ} \mathrm{C}$. The hydrogen permeation follows a solution-diffusion mechanism, and the hydrogen flux can be universally described as $J=F\left(p_{\mathrm{r}}{ }^{n}-p_{\mathrm{p}}{ }^{n}\right)$, where $J$ is the hydrogen flux $\left(\mathrm{m}^{3} /\left(\mathrm{m}^{2} \cdot \mathrm{h}\right)\right), F$ is the hydrogen permeance $\left(\mathrm{m}^{3} /\left(\mathrm{m}^{2} \cdot \mathrm{h} \cdot \mathrm{MPa}^{n}\right)\right), p_{\mathrm{r}}$ and $p_{\mathrm{p}}$ are the pressures (MPa) at the retentate and permeate sides, and $n$ is the pressure exponent $(0.5 \leq n \leq 1)$. In general, the hydrogen diffusion in the bulk of the Pd layer is the rate determining step, and the hydrogen permeation kinetics obeys the Sievert's Law $[16,17]$, i.e., $n=0.5$.

The testing results are shown in Fig. 4, where the membrane selectivity is defined as the ratio of $\mathrm{H}_{2}$ flux to $\mathrm{N}_{2}$ flux under the same temperature and pressure. The higher the selectivity, the fewer the membrane defects are. During testing, the $\mathrm{NiO}$ in the

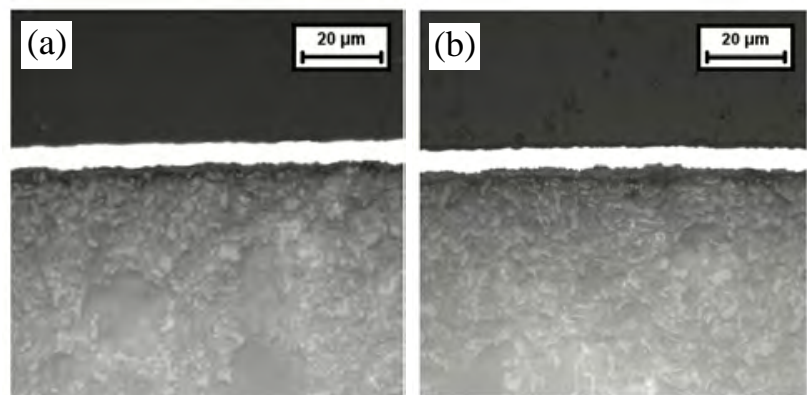

Fig. 3. Metallographic micrographs of the cross-sections of Pd/Pencil/ $\mathrm{Al}_{2} \mathrm{O}_{3}$ (a) and $\mathrm{Pd} /$ Pencil/NiO/ $/ \mathrm{Al}_{2} \mathrm{O}_{3}$ (b) membranes. 

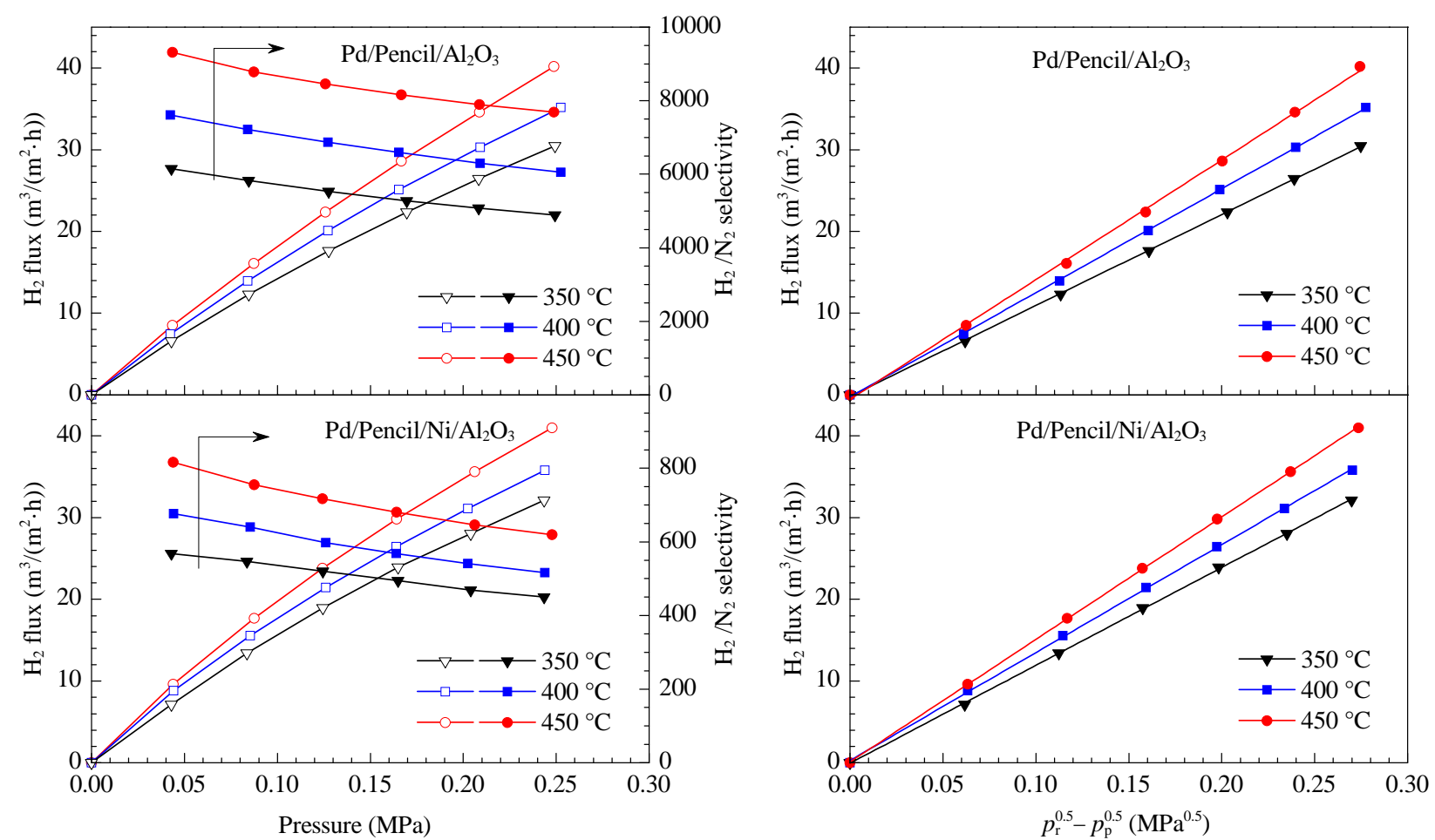

Fig. 4. Permeation performance of $\mathrm{Pd} / \mathrm{Pencil} / \mathrm{Al}_{2} \mathrm{O}_{3}$ and $\mathrm{Pd} / \mathrm{Pencil} / \mathrm{Ni} / \mathrm{Al}_{2} \mathrm{O}_{3}$ membranes.

$\mathrm{Pd} / \mathrm{Pencil} / \mathrm{NiO} / \mathrm{Al}_{2} \mathrm{O}_{3}$ was reduced in situ by hydrogen, and a $\mathrm{Pd} /$ Pencil/Ni/ $\mathrm{Al}_{2} \mathrm{O}_{3}$ membrane was obtained.

It has been already found in our previous work that the pencil coating can effectively avoid the problem of the substrate surface defects and consequently facilitate the membrane preparation [12]. However, the original intention of this work is to investigate the effects of the nickel catalyst on the methanation of $\mathrm{CO}$ leaked through membrane defects, and therefore a $\mathrm{Pd} / \mathrm{Pencil} / \mathrm{Ni} / \mathrm{Al}_{2} \mathrm{O}_{3}$ membrane with a lower $\mathrm{H}_{2} / \mathrm{N}_{2}$ selectivity was selected. The permeation results are shown in Fig. 4. The $\mathrm{H}_{2} / \mathrm{N}_{2}$ selectivities of the $\mathrm{Pd} / \mathrm{Pencil} / \mathrm{Al}_{2} \mathrm{O}_{3}$ and $\mathrm{Pd} /$ Pencil/Ni $/ \mathrm{Al}_{2} \mathrm{O}_{3}$ membranes were $>5000$ and $<1000$, respectively. The best linear correlation between the hydrogen flux and the pressure can be established when $n=0.5$, indicating that the hydrogen permeation kinetics obeys the Sievert's Law. At 350,400 , and $450{ }^{\circ} \mathrm{C}$, the hydrogen permeabilities of the $\mathrm{Pd} / \mathrm{Pencil} / \mathrm{Al}_{2} \mathrm{O}_{3}$ membrane were 110,126 , and 144 $\mathrm{m}^{3} /\left(\mathrm{m}^{2} \cdot \mathrm{h} \cdot \mathrm{MPa}^{0.5}\right)$, while those of the $\mathrm{Pd} / \mathrm{Pencil} / \mathrm{Ni}^{-} \mathrm{Al}_{2} \mathrm{O}_{3}$ membrane were 120,133 , and $150 \mathrm{~m}^{3} /\left(\mathrm{m}^{2} \cdot \mathrm{h} \cdot \mathrm{MPa}^{0.5}\right)$, respectively. It can be concluded that the permeabilities of the two membranes are quite close.

The results in Fig. 4 reveal that the deposition of the nickel catalyst has little influence on the permeation performance of the palladium membrane. At first, the nickel catalyst has been deposited into the pores of the $\mathrm{Al}_{2} \mathrm{O}_{3}$ substrate, and it does not contact with the palladium layer because of the pencil coating layer on $\mathrm{Al}_{2} \mathrm{O}_{3}$ so that it will not contaminate the palladium membrane or hamper the membrane preparation. Secondly, the amount of the nickel deposition is too low to cause significant resistance for gas diffusion. Thirdly, the hydrogen diffusion resistance of the substrate is much lower than that of the palladium layer, the hydrogen atom diffusion in palladium bulk remains to be the rate determining step, and this is consistent with the kinetic results in Fig. 4. For each of the two membranes, both the hydrogen permeability and the $\mathrm{H}_{2} / \mathrm{N}_{2}$ selectivity increase with increasing temperature, and this is a typical feature of a palladium membrane. The leakage of nitrogen through the defects of a palladium membrane often follows Knudsen and Poiseuile diffusions, and the $\mathrm{N}_{2}$ flux is proportional to the $T^{-0.5}$ and $T^{-1}$, that is, it decreases with increasing temperature.

\subsection{Hydrogen separation and CO methanation performance}

Under the practical conditions, the impurities in the feed hydrogen will decrease the permeability of the Pd membranes [18-20]. Apart from the pressure, temperature, and feed gas composition, the expected hydrogen recovery will also influence the capacity and the hydrogen output of the palladium membranes. When the hydrogen feed flows at the retentate side of a palladium membrane, the hydrogen concentration and partial pressure gradually decrease because of the hydrogen separation, and the corresponding local hydrogen flux also decreases. For a given palladium membrane, an increase in the hydrogen feed rate will lead to a decrease in the hydrogen recovery (because of the insufficient hydrogen separation) and an increase in the purified hydrogen producibility (because of the high hydrogen partial pressure). Therefore, a higher hydrogen recovery means a lower producibility of the purified hydrogen. Once the hydrogen partial pressure of the membrane retentate offgas equals to the pressure of the membrane permeate hydrogen, the hydrogen recovery reaches a maxi- 

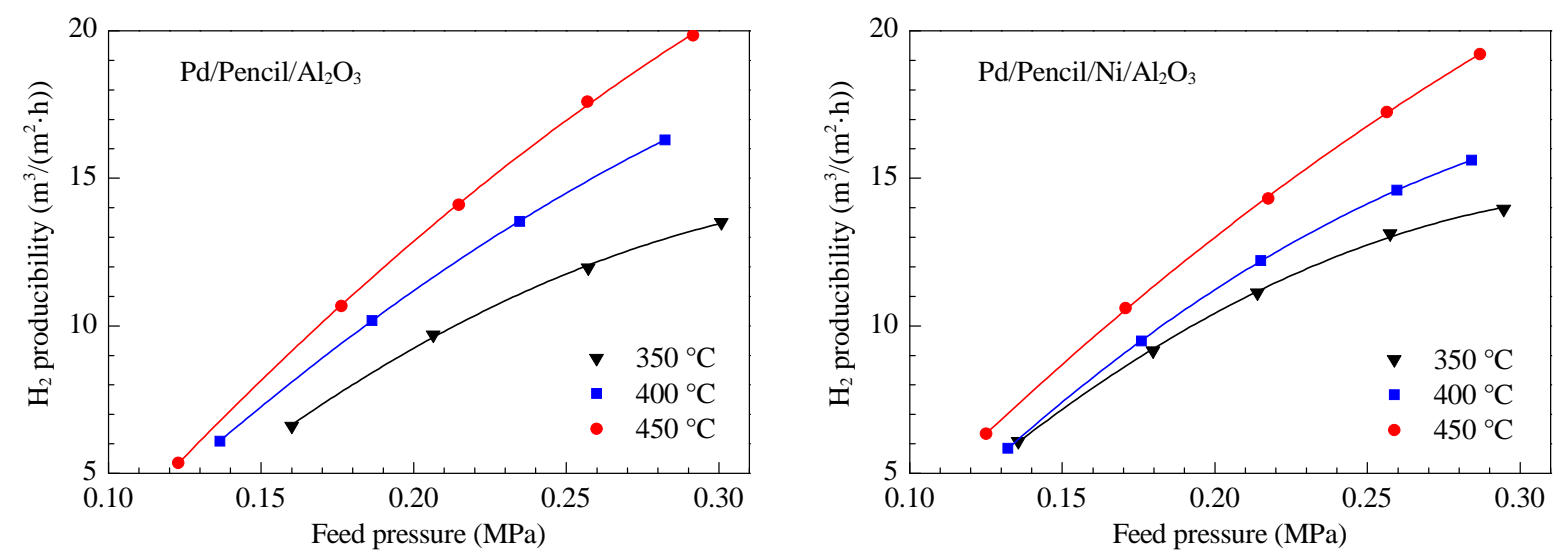

Fig. 5. Hydrogen producibility as a function of feed pressure (hydrogen recovery, 70\%).

mum. Both the increase in the membrane retentate pressure and the decrease in membrane permeate pressure are effective in improving the membrane producibility and the hydrogen recovery.

In this work, the membrane producibility as a function of the feed pressure was tested with a feed gas, whose composition is $\mathrm{H}_{2} 77.8 \%$, $\mathrm{CO} 5.2 \%, \mathrm{CO}_{2} 13.5 \%$, and $\mathrm{CH}_{4} 3.5 \%$, and the hydrogen recovery was maintained at $70 \%$. The results are exhibited in Fig. 5. No significant difference between the hydrogen producibilities of the $\mathrm{Pd} / \mathrm{Pencil} / \mathrm{Al}_{2} \mathrm{O}_{3}$ and $\mathrm{Pd} / \mathrm{Pencil} /$ $\mathrm{Ni} / \mathrm{Al}_{2} \mathrm{O}_{3}$ membranes can be observed at the same temperature and feed pressure. For example, the hydrogen producibilities of the $\mathrm{Pd} / \mathrm{Pencil} / \mathrm{Al}_{2} \mathrm{O}_{3}$ membrane under a feed pressure of 0.25 $\mathrm{MPa}$ at 350,400 , and $450{ }^{\circ} \mathrm{C}$ are $11.8,14.5$, and $17.0 \mathrm{~m}^{3} /\left(\mathrm{m}^{2} \cdot \mathrm{h}\right)$, while corresponding those of the $\mathrm{Pd} / \mathrm{Pencil} / \mathrm{Ni} / \mathrm{Al}_{2} \mathrm{O}_{3}$ membrane are $12.7,14.1$, and $16.8 \mathrm{~m}^{3} /\left(\mathrm{m}^{2} \cdot \mathrm{h}\right)$, respectively.

The purity of the hydrogen after membrane separation depends on the feed gas composition, the membrane operating conditions, and the membrane integrity. During membrane preparation and the long-term operation, pinholes may appear on the membrane and cause a decrease in hydrogen purity. It was well known that the PEM fuel cells are extremely sensitive to CO. Aiming at this characteristic, this work introduced a nickel catalyst into the pores of the $\mathrm{Al}_{2} \mathrm{O}_{3}$ substrate so that the CO leaked through membrane defects can be methanized. Under the action of the methanation catalyst, both $\mathrm{CO}$ and $\mathrm{CO}_{2}$ can be hydrogenated according to the following reactions:

$$
\begin{aligned}
\mathrm{CO}+3 \mathrm{H}_{2} & \rightarrow \mathrm{CH}_{4}+\mathrm{H}_{2} \mathrm{O} \\
\mathrm{CO}_{2}+4 \mathrm{H}_{2} & \rightarrow \mathrm{CH}_{4}+2 \mathrm{H}_{2} \mathrm{O}
\end{aligned}
$$

Eventually, the $\mathrm{Pd} / \mathrm{Pencil} / \mathrm{Ni} / \mathrm{Al}_{2} \mathrm{O}_{3}$ membrane possessed both functions of hydrogen separation and CO methanation, and the principle is shown in Fig. 6. Despite that 1 mol CO and
$\mathrm{CO}_{2}$ will consume 3 and $4 \mathrm{~mol} \mathrm{H}_{2}$ and produce 2 and 3 moles of new impurities, respectively, the produced small amount of $\mathrm{CH}_{4}$ and $\mathrm{H}_{2} \mathrm{O}$ will be of no poisoning or side effect for PEM fuel cells. Since the concentrations of the leaked $\mathrm{CO}$ and $\mathrm{CO}_{2}$ through the palladium membrane are so low, the consumed hydrogen during the methanation reactions is negligible.

The concentrations of $\mathrm{CO}, \mathrm{CO}_{2}$ and $\mathrm{CH}_{4}$ in the hydrogen permeated through the $\mathrm{Pd} / \mathrm{Pencil} / \mathrm{Al}_{2} \mathrm{O}_{3}$ and $\mathrm{Pd} / \mathrm{Pencil} / \mathrm{Ni} /$ $\mathrm{Al}_{2} \mathrm{O}_{3}$ membranes at a feed pressure of $0.25 \mathrm{MPa}$ and a hydrogen recovery of $70 \%$ are listed in Table 1 . After separation by the $\mathrm{Pd} / \mathrm{Pencil} / \mathrm{Al}_{2} \mathrm{O}_{3}$ membrane, the concentrations of $\mathrm{CO}, \mathrm{CO}_{2}$, and $\mathrm{CH}_{4}$ are three orders of magnitude lower than those in the feed gas, indicating the excellent membrane separation effect. Compared with those for the $\mathrm{Pd} / \mathrm{Pencil} / \mathrm{Al}_{2} \mathrm{O}_{3}$ membrane, the concentrations of $\mathrm{CO}$ and $\mathrm{CO}_{2}$ after separation by the Pd/Pencil/ $\mathrm{Ni} / \mathrm{Al}_{2} \mathrm{O}_{3}$ membrane are at least one order of magnitude lower, but the concentration of $\mathrm{CH}_{4}$ is two orders of magnitude higher. Obviously, these results are due to the catalytic methanation effect by the $\mathrm{Pd} / \mathrm{Pencil} / \mathrm{Ni} / \mathrm{Al}_{2} \mathrm{O}_{3}$ membrane. As already proved by the results in Fig. 4 , the $\mathrm{Pd} / \mathrm{Pencil} / \mathrm{Ni} / \mathrm{Al}_{2} \mathrm{O}_{3}$ has more defects than the $\mathrm{Pd} / \mathrm{Pencil} / \mathrm{Al}_{2} \mathrm{O}_{3}$, but the concentrations of $\mathrm{CO}$ and $\mathrm{CO}_{2}$ for the $\mathrm{Pd} / \mathrm{Pencil} / \mathrm{Ni} / \mathrm{Al}_{2} \mathrm{O}_{3}$ are significantly lower than those for the $\mathrm{Pd} / \mathrm{Pencil} / \mathrm{Al}_{2} \mathrm{O}_{3}$, indicating that the $\mathrm{CO}$

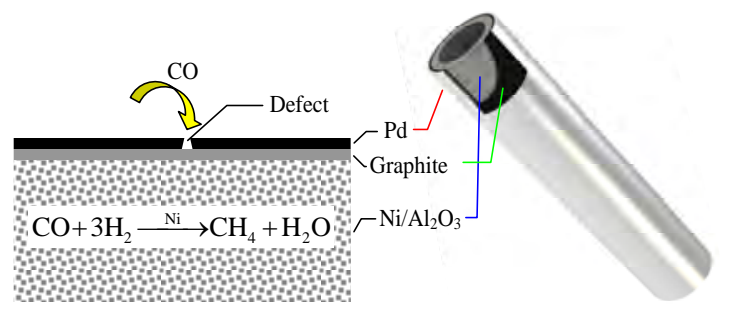

Fig. 6. Mechanism of the bifunctional $\mathrm{Pd} / \mathrm{Pencil} / \mathrm{Ni} / \mathrm{Al}_{2} \mathrm{O}_{3}$ membrane.

Table 1

Concentrations of $\mathrm{CO}, \mathrm{CO}_{2}$, and $\mathrm{CH}_{4}$ in the hydrogen permeated from the Pd membranes at different temperatures under a feed pressure of $0.25 \mathrm{MPa}$

\begin{tabular}{|c|c|c|c|c|c|c|c|}
\hline \multirow{3}{*}{ Impurity } & \multirow{3}{*}{ Feed } & \multicolumn{6}{|c|}{ Concentration (\%) } \\
\hline & & \multicolumn{3}{|c|}{$\mathrm{Pd} /$ Pencil/ $/ \mathrm{Al}_{2} \mathrm{O}_{3}$} & \multicolumn{3}{|c|}{$\mathrm{Pd} /$ Pencil/Ni/ $/ \mathrm{Al}_{2} \mathrm{O}_{3}$} \\
\hline & & $350^{\circ} \mathrm{C}$ & $400^{\circ} \mathrm{C}$ & $450^{\circ} \mathrm{C}$ & $350^{\circ} \mathrm{C}$ & $400^{\circ} \mathrm{C}$ & $450^{\circ} \mathrm{C}$ \\
\hline$\overline{\mathrm{CH}_{4}}$ & 3.5 & $5.4 \times 10^{-3}$ & $3.9 \times 10^{-3}$ & $2.8 \times 10^{-3}$ & 0.36 & 0.35 & 0.22 \\
\hline $\mathrm{CO}$ & 5.2 & $5.6 \times 10^{-3}$ & $4.5 \times 10^{-3}$ & $3.6 \times 10^{-3}$ & $1.0 \times 10^{-4}$ & $-\mathrm{a}$ & $-\mathrm{a}$ \\
\hline $\mathrm{CO}_{2}$ & 13.5 & $1.8 \times 10^{-2}$ & $1.5 \times 10^{-2}$ & $1.0 \times 10^{-2}$ & $5.4 \times 10^{-3}$ & $2.9 \times 10^{-4}$ & $1.0 \times 10^{-4}$ \\
\hline
\end{tabular}
and a hydrogen recovery of $70 \%$.

${ }^{\mathrm{a}}$ Below $5 \times 10^{-5} \%$. 


\section{Graphical Abstract}

Chin. J. Catal., 2013, 34: 1720-1729 doi: 10.1016/S1872-2067(12)60636-6

\section{Bifunctional palladium composite membrane for hydrogen separation} and catalytic CO methanation

Xiaojuan Hu, Wenjun Yan, Weihua Ding, Jian Yu, Yan Huang* Nanjing University of Technology

Aiming at the hydrogen purification for proton exchange membrane fuel cells, a bifunctional Pd/Pencil/Ni/ $\mathrm{Al}_{2} \mathrm{O}_{3}$ membrane that is capable of hydrogen separation and catalytic $\mathrm{CO}$ methanation was developed. It was compared with the $\mathrm{Pd} / \mathrm{Pencil} / \mathrm{Al}_{2} \mathrm{O}_{3}$ membrane without the nickel methanation catalyst.

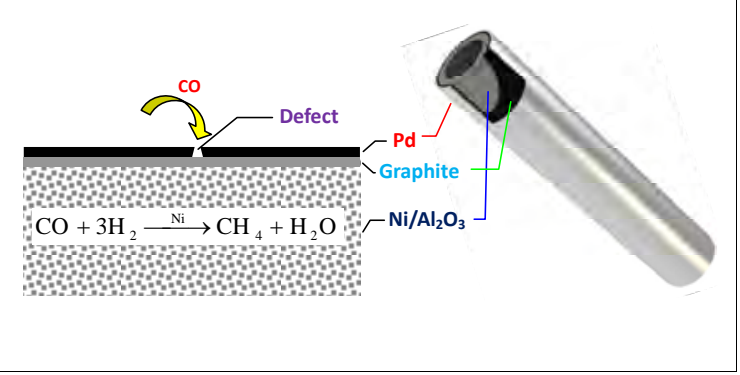

and $\mathrm{CO}_{2}$ has been converted or eliminated by the Pd/Pencil/ $\mathrm{Ni} / \mathrm{Al}_{2} \mathrm{O}_{3}$. Moreover, the ratios among the concentrations of $\mathrm{CO}$, $\mathrm{CO}_{2}$, and $\mathrm{CH}_{4}$ in the hydrogen from the $\mathrm{Pd} / \mathrm{Pencil} / \mathrm{Al}_{2} \mathrm{O}_{3}$ were close to those in the feed gas, while the concentration of $\mathrm{CH}_{4}$ in the hydrogen from the $\mathrm{Pd} / \mathrm{Pencil} / \mathrm{Ni} / \mathrm{Al}_{2} \mathrm{O}_{3}$ membrane was greatly higher than those of $\mathrm{CO}$ and $\mathrm{CO}_{2}$, indicating that the $\mathrm{Pd} /$ Pencil/Ni/ $/ \mathrm{Al}_{2} \mathrm{O}_{3}$ membrane is effective in methanation of $\mathrm{CO}$ and $\mathrm{CO}_{2}$. Since the concentration of $\mathrm{CO}$ in hydrogen from the $\mathrm{Pd} / \mathrm{Pencil} / \mathrm{Ni} / \mathrm{Al}_{2} \mathrm{O}_{3}$ membrane is below $0.0001 \%$, the requirement of the PEM fuel cells can be fully satisfied. The results in Table 1 also reveal that an increase in temperature tends to cause a decrease in the concentrations of $\mathrm{CO}, \mathrm{CO}_{2}$, and $\mathrm{CH}_{4}$, and this coincides with the results in Fig. 4, i.e., the membrane selectivity increases with increasing temperature.

Like nickel, the palladium is also a well known methanation catalyst [21], but the palladium particle size of conventional palladium catalysts is in nanometer scale, and the palladium membrane will not generate significant methanation activity because of the small surface area. Moreover, the Pd layer is very thin and distributed only on the substrate surface, and the contact time of the $\mathrm{CO}$ and $\mathrm{CO}_{2}$ leaked through membrane defects is extremely short. Therefore, significant methanation effect will not occur on the conventional palladium membranes (such as $\mathrm{Pd} / \mathrm{Pencil} / \mathrm{Al}_{2} \mathrm{O}_{3}$ ), and that on the $\mathrm{Pd} / \mathrm{Pencil} / \mathrm{Ni} / \mathrm{Al}_{2} \mathrm{O}_{3}$ membrane is obviously ascribed to the introduced nickel catalyst. Such a bifunctional membrane is particularly suitable for the hydrogen separation for PEM fuel cells. On one hand, it solved the problem that the PEM fuel cells are extremely sensitive to the CO in hydrogen; on the other hand, it increased the tolerance against the appearance of membrane defects, and this is equivalent to prolong the life of the palladium membrane.

\section{Conclusions}

A bifunctional palladium membrane $\mathrm{Pd} / \mathrm{Pencil} / \mathrm{Ni} / \mathrm{Al}_{2} \mathrm{O}_{3}$ with capacities of both hydrogen separation and catalytic CO methanation was successfully developed by introduction of $\mathrm{Ni}$ catalyst into the porous $\mathrm{Al}_{2} \mathrm{O}_{3}$ substrate. It not only solves the problem that the PEM fuel cells are extremely sensitive to the CO in hydrogen but also prolongs the life of the palladium membrane. Moreover, the hydrogen that is consumed during methanation reactions is negligible because the amount of the $\mathrm{CO}$ and $\mathrm{CO}_{2}$ leaked through membrane defects is very low.
Therefore, the bifunctional $\mathrm{Pd} / \mathrm{Pencil} / \mathrm{Ni} / \mathrm{Al}_{2} \mathrm{O}_{3}$ membrane is particularly ideal for hydrogen separation for PEM fuel cells. According to the preparation process of the bifunctional membrane in this work, the introduction of nickel catalyst almost has no influence on the preparation and performance of the palladium membrane itself, and the pencil coating not only modified the $\mathrm{Al}_{2} \mathrm{O}_{3}$ substrate surface but also avoided the direct contact between nickel catalyst and palladium membrane. The nickel-free palladium membrane $\mathrm{Pd} / \mathrm{Pencil} / \mathrm{Al}_{2} \mathrm{O}_{3}$ showed no significant activity on catalytic $\mathrm{CO}$ methanation.

\section{References}

[1] Biyikoğlu A. Int J Hydrogen Energy, 2005, 30: 1181

[2] Chandan A, Hattenberger M, El-kharouf A, Du S F, Dhir A, Self V, Pollet B G, Ingram A, Bujalski W. J Power Sources, 2013, 231: 264

[3] Shi W Y, Yi B L, Hou M, Shao Z G. Int J Hydrogen Energy, 2007, 32 : 4412

[4] Kim H T, Yoo J S, Joh H-I, Kim H, Heop S. Int J Hydrogen Energy, 2011, 36: 1606

[5] Chen W-H, Syu W-Z, Hung C-I, Lin Y-L, Yang C-C. Int J Hydrogen Energy, 2013, 38: 1145

[6] Mukaida M, Takahashi N, Hisamatsu K, Ishitsuka M, Hara S, Suda H, Haraya K. J Membr Sci, 2010, 365: 378

[7] Kim Y H, Yim S-D, Park E D. Catal Today, 2012, 185: 143

[8] Zhang J G, Jia J S, Zhang C X, Wang S D. Chin J Catal (张建国, 郏景 省, 张纯希, 王树东. 催化学报), 2008, 29: 421

[9] Liu Y, Wang S, Gao D N, Wang S D. Chin J Catal (刘芗, 王胜, 高典 楠, 王树东. 催化学报), 2012, 33: 1254

[10] Guo F, Chu W, Xu H Y, Zhang T. Chin J Catal (郭芳, 储伟, 徐慧远, 张涛. 催化学报), 2007, 28: 429

[11] Huang Y, Yan W J, Hu X J. CN Patent 102441 330A. 2012

[12] Hu X J, Chen W D, Huang Y. Int J Hydrogen Energy, 2010, 35: 7803

[13] Huang Y, Hu X J, Chen W D. US Patent 8445 055. 2013

[14] Chen W D, Hu X J, Wang R X, Huang Y. Sep Purif Tech, 2010, 72: 92

[15] Yu J, Hu X J, Huang Y. Sep Purif Technol, 2010, 70: 314

[16] Paglieri S N, Way J D. Sep Purif Methods, 2002, 31: 1

[17] Ward T L, Dao T.J Membr Sci, 1999, 153: 211

[18] Zhang J, Liu D Y, He M F, Xu H Y, Li W Z.J Membr Sci, 2006, 274: 83

[19] Peters T A, Stange M, Klette H, Bredesen R. J Membr Sci, 2008, 316 : 119

[20] Amandusson H, Ekedah L G, Dannetun H. J Membr Sci, 2001, 193: 35

[21] Gu Y J, Zhong S H. Chin J Catal (顾永健, 钟顺和. 催化学报), 2006, 27: 250 


\section{氢分离与CO催化甲烷化双功能型钯复合膜 \\ 胡小娟, 严文俊, 丁维华, 俞 健, 黄 彦 ${ }^{*}$ 南京工业大学化学化工学院, 材料化学工程国家重点实验室, 江苏南京210009}

摘要: 以多孔 $\mathrm{Al}_{2} \mathrm{O}_{3}$ 陶瓷为基体材料, 采用浸渍法担载 $\mathrm{NiO}$ 后用 $2 \mathrm{~B}$ 铅笔修饰 $\mathrm{NiO} / \mathrm{Al}_{2} \mathrm{O}_{3}$ 表面, 通过化学镀法沉积约 $5 \mu \mathrm{m}$ 厚的金属钯, 还原后成功制得 $\mathrm{Pd} / \mathrm{Pencil} / \mathrm{Ni} / \mathrm{Al}_{2} \mathrm{O}_{3}$ 膜. 为进行对比, 还制备了未担载镍的 $\mathrm{Pd} / \mathrm{Pencil} / \mathrm{Al}_{2} \mathrm{O}_{3}$ 膜. 膜的表面和断面形貌分别采用扫描电 镜和金相显微镜观测, 膜的透氢动力学通过 $\mathrm{H}_{2} / \mathrm{N}_{2}$ 单气体法测试, 并以成分为 $\mathrm{H}_{2} 77.8 \%, \mathrm{CO} 5.2 \%, \mathrm{CO}_{2} 13.5 \%$ 和 $\mathrm{CH}_{4} 3.5 \%$ 的原料氢测 定了膜的氢分离效果. 结果表明, 未载镍的 $\mathrm{Pd} / \mathrm{Pencil} / \mathrm{Al}_{2} \mathrm{O}_{3}$ 膜只具有氢分离作用, 而 $\mathrm{Pd} / \mathrm{Pencil} / \mathrm{Ni} / \mathrm{Al}_{2} \mathrm{O}_{3}$ 膜还可以有效地将钯膜泄漏 的 $\mathrm{CO}$ 和 $\mathrm{CO}_{2}$ 转化为甲烷, 因而成为双功能型钯膜. 这种双功能膜尤其适用于面向质子交换膜燃料电池(PEMFC)的氢气分离, 既有 效解决了 PEMFC对氢燃料中CO格外敏感的难题, 又提高了对钯膜缺陷的容忍度, 因而延长了钯膜的使用寿命.

关键词: 钯膜; 氢分离; 一氧化碳甲烷化; 双功能; 镍催化剂; 质子交换膜燃料电池

收稿日期: 2013-04-30. 接受日期: 2013-06-17. 出版日期: 2013-09-20.

*通讯联系人. 电话: (025)83172253; 电子信箱: huangy@njut.edu.cn

基金来源：江苏省高校自然科学基金(09KJA530003); 中国博士后科学基金(2011M501220); 江苏省博士后科研资助计划 (1102090C).

本文的英文电子版由Elsevier出版社在ScienceDirect上出版(http://www.sciencedirect.com/science/journal/18722067).

\section{1. 前言}

与氢气的工业化生产不同, 面向氢能的产氢系统对 小型化和便携性都提出了很高要求. 氢分离是产氢系统 的关键单元, 在各种氢分离工艺中, 膜分离法具有突出 的优势. 质子交换膜燃料电池(PEMFC) 是最为成熟的氢 能电源 ${ }^{[1,2]}$, 它的阳极含有 $\mathrm{Pt}$ 催化剂, 能在室温下将氢气 催化氧化为水并产生电能, 但对氢气纯度要求较高. 目 前, PEMFC所用的氢燃料主要来源于化石原料的水蒸气 重整反应, 难免含有少量CO杂质. 由于CO极容易毒化 $\mathrm{Pt}$ 催化剂, 燃料氢中的CO含量一般必须控制在 $0.001 \%$ 以 下 $^{[3,4]}$, 这就对膜分离选择性提出了极为苛刻的要求. 在 各种氢气分离膜中, 性能最为突出的当属钯和钯合金膜, 该膜不仅透氢性好, 而且具有无与伦比的渗透选择性, 能阻挡其它任何气体. 另一方面, 有针对性地消除氢中 的CO则能够起到事半功倍的效果. 除膜分离法 ${ }^{[5,6]}$ 之外, 氢中少量CO的消除主要有选择氧化 ${ }^{[7,8]}$ 和甲烷化 ${ }^{[9,10]}$ 法. 选择氧化法是在避免 $\mathrm{H}_{2}$ 氧化的情况下将 $\mathrm{CO}$ 催化氧化为 $\mathrm{CO}_{2}$, 但该法需通入适量 $\mathrm{O}_{2}$ 且对催化剂选择性要求较高. 甲烷化法是在催化剂的作用下将 $\mathrm{CO}$ 与 $\mathrm{H}_{2}$ 反应生成 $\mathrm{CH}_{4}$. 除 $\mathrm{CO}$ 外, 工业氢气中往往还含有 $\mathrm{CO}_{2}$, 在甲烷化过程中 也会被转化. 每 $1 \mathrm{~mol}$ 的 $\mathrm{CO}$ 和 $\mathrm{CO}_{2}$ 分别要消耗 3 和 $4 \mathrm{~mol}$ 的 $\mathrm{H}_{2}$, 因此当原料氢中 $\mathrm{CO}$ 和 $\mathrm{CO}_{2}$ 的量较多时不宜直接采 用甲烷化法.

商业化的钯合金膜通常采用冷轧法制备, 厚度多在 $50 \mu \mathrm{m}$ 以上, 存在机械强度差、透氢率低、成本高等缺点,
因此膜分离法也受到巨大限制. 为此, 将钯膜担载于多 孔基体材料形成的钯复合膜则成为人们关注的焦点, 其 膜厚一般仅为传统钯合金膜的 $1 / 10$. 然而, 钯复合膜的 稳定性是限制其工业化应用的关键因素, 因为在长期运 行过程中, 钯复合膜会逐渐产生针孔, 导致氢纯度逐渐 下降, 一旦CO浓度超出燃料电池的容忍限度, 则意味着 钯复合膜的寿命结束. 鉴于PEMFC对CO极其敏感, 则 钯复合膜的寿命势必成为关键问题. 针对甲烷化法和膜 分离法的特点, 本课题组发明了一种双功能膜 ${ }^{[11]}$, 即在 钯复合膜的多孔基体材料中担载甲烷化催化剂, 从而实 现了膜分离与甲烷化过程的耦合. 一方面, 甲烷化过程 降低了对钯复合膜CO泄漏量的苛刻要求, 相当于直接 延长了钯复合膜的使用寿命; 另一方面, 经过钯复合膜 的分离, 氢气中的 $\mathrm{CO}$ 和 $\mathrm{CO}_{2}$ 浓度已处于极低水平, 此时 进行甲烷化处理则耗氢量完全可以忽略不计.

本工作制备了具有氢分离和CO甲烷化双功能的钯 复合膜 $\mathrm{Pd} / \mathrm{Pencil} / \mathrm{Ni} / \mathrm{Al}_{2} \mathrm{O}_{3}$, 并对比了其与不含镍催化剂的 $\mathrm{Pd} / \mathrm{Pencil} / \mathrm{Al}_{2} \mathrm{O}_{3}$ 膜的氢分离性能.

\section{2. 实验部分}

\section{1. 膜的制备}

\subsection{1. 在 $\mathrm{Al}_{2} \mathrm{O}_{3}$ 基体上担载 $\mathrm{NiO}$}

所用基体材料为普通多孔 $\mathrm{Al}_{2} \mathrm{O}_{3}$ 陶瓷管, 长 $75 \mathrm{~mm}$, 外径 $13 \mathrm{~mm}$, 内径 $8 \mathrm{~mm}$. 先用市售洗洁精溶液煮洗, 然 后用去离子水反复漂洗, 最后置于烘箱中 $120^{\circ} \mathrm{C}$ 干燥.

采用浸渍法制备 $\mathrm{NiO} / \mathrm{Al}_{2} \mathrm{O}_{3}$. 将 $\mathrm{Al}_{2} \mathrm{O}_{3}$ 基体在 
$\mathrm{Ni}\left(\mathrm{NO}_{3}\right)_{2}$ 溶液 $(0.25 \mathrm{~mol} / \mathrm{L})$ 中浸泡 $10 \mathrm{~h}$, 在 $120^{\circ} \mathrm{C}$ 干燥 $12 \mathrm{~h}$ 后再在 $450{ }^{\circ} \mathrm{C}$ 下焙烧 $3 \mathrm{~h}$. 通过称重法算得基体中的 $\mathrm{NiO}$ 含量为 $3.6 \%$, 折合金属镍含量为 $2.8 \%$.

\subsection{2. 表面修饰}

$\mathrm{Al}_{2} \mathrm{O}_{3}$ 基体和 $\mathrm{NiO} / \mathrm{Al}_{2} \mathrm{O}_{3}$ 的表面采用石墨涂层法修 饰 ${ }^{[12,13]}$, 用市售2B铅笔在基体表面涂划以产生均匀、连续 的修饰层, 在 $450{ }^{\circ} \mathrm{C}$ 下焙烧 $3 \mathrm{~h}$ 以除去油污, 得到 Pencil/ $/ \mathrm{Al}_{2} \mathrm{O}_{3}$ 和Pencil/NiO/ $/ \mathrm{Al}_{2} \mathrm{O}_{3}$.

\subsection{3. 化学镀 ${ }^{[14]}$}

将 Pencil/ $/ \mathrm{Al}_{2} \mathrm{O}_{3}$ 和 Pencil/ $\mathrm{NiO} / \mathrm{Al}_{2} \mathrm{O}_{3}$ 预先采用 $\mathrm{SnCl}_{2} /$ $\mathrm{PdCl}_{2}$ 法活化. 其中, 敏化液含 $\mathrm{SnCl}_{2} 5 \mathrm{~g} / \mathrm{L}$ 和浓盐酸 $1 \mathrm{ml} / \mathrm{L}$, 活化液含 $\mathrm{PdCl}_{2} \quad 0.2 \mathrm{~g} / \mathrm{L}$ 和浓盐酸 $1 \mathrm{ml} / \mathrm{L}$. 化学镀操作温度 为 $30{ }^{\circ} \mathrm{C}$, 镀液组成为 $\mathrm{PdCl}_{2} 5 \mathrm{~g} / \mathrm{L}, \mathrm{Na}_{2}$ EDTA $70 \mathrm{~g} / \mathrm{L}$ 和浓氨 水 $(28 \%) 250 \mathrm{ml} / \mathrm{L}$. 还原剂为 $0.2 \mathrm{~mol} / \mathrm{L}$ 的 $\mathrm{N}_{2} \mathrm{H}_{4}$ 溶液. 钯膜 的厚度通过镀液用量控制, 若没有钯的损失, 膜厚将为5 $\mu \mathrm{m}$.

\section{2. 膜的表征与氢分离性能测试}

多孔陶瓷基体的孔径采用孔径分析仪 (GaoQ PSDA-20)通过泡点法 (又称气液排出法、毛细流动法) 测 量 ${ }^{[15]}$. 样品的表面形貌分析采用扫描电镜(FEI Quanta-200)进行. 钯膜的断面结构采用金相显微镜 (Leica DM-4000M) 观测, 但预先将样品用环氧树脂镶嵌并用磨 抛机(Buehler Phenix Beta)打磨、抛光.

将所制钯复合膜安装于膜组件(GaoQ PM-201S). 膜 的透氢动力学采用 $\mathrm{H}_{2} / \mathrm{N}_{2}$ 单气体法表征, 并以混合气 $\left(\mathrm{H}_{2}\right.$ $77.8 \%, \mathrm{CO} 5.2 \%, \mathrm{CO}_{2} 13.5 \%$ 和 $\mathrm{CH}_{4} 3.5 \%$ ) 为原料气测试膜 的实际氢分离性能. 膜管外侧为滞留侧, 压力可调; 膜管 内侧为渗透侧, 压力为常压. 测试过程中, 钯膜基体材料 中的 $\mathrm{NiO}$ 在氢气通入后被原位还原为金属镍催化剂. 渗 透侧气体成分采用气相色谱仪(岛津GC-2014)在线分析.

\section{3. 结果与讨论}

\section{1. 膜的形貌}

多孔 $\mathrm{Al}_{2} \mathrm{O}_{3}$ 陶瓷是最常见的钯膜基体材料, 而在本工 作中它还被用作甲烷化催化剂的载体. 孔径分析结果表 明, 其最大孔径和平均孔径分别为 1.5 和 $3.7 \mu \mathrm{m}$. 文献报道 的钯膜基体材料平均孔径多在 $0.2 \mu \mathrm{m}$ 以下, 需做成非对称 结构以控制孔径并降低扩散阻力, 价格较为昂贵. 本工作 选用普通大孔陶瓷为基体材料, 有利于降低钯膜成本并 实现产业化. 图 1 示出了 $\mathrm{Al}_{2} \mathrm{O}_{3}$ 基体, $\mathrm{NiO} / \mathrm{Al}_{2} \mathrm{O}_{3}$, Pencil/ $/ \mathrm{Al}_{2} \mathrm{O}_{3}, \mathrm{Pencil} / \mathrm{NiO} / \mathrm{Al}_{2} \mathrm{O}_{3}, \mathrm{Pd} / \mathrm{Pencil} / \mathrm{Al}_{2} \mathrm{O}_{3}$ 膜和Pd/Pencil/ $\mathrm{NiO} / \mathrm{Al}_{2} \mathrm{O}_{3}$ 膜的照片. $\mathrm{Al}_{2} \mathrm{O}_{3}$ 基体材料表面较为粗粘.
$\mathrm{NiO} / \mathrm{Al}_{2} \mathrm{O}_{3}$ 呈黑色且颜色分布均匀. Pencil/ $/ \mathrm{Al}_{2} \mathrm{O}_{3}$ 和 $\mathrm{Pencil} / \mathrm{NiO} / \mathrm{Al}_{2} \mathrm{O}_{3}$ 表面均呈石墨颜色且十分光滑. 实际上, 石墨铅笔修饰工艺是我们课题组专门为修饰大孔基体而 开发的 ${ }^{[12,13]}$, 不仅操作简便, 成本低廉, 而且几乎没有污 染. 本工作制得的钯膜 $\mathrm{Pd} / \mathrm{Pencil} / \mathrm{Al}_{2} \mathrm{O}_{3}$ 和 $\mathrm{Pd} / \mathrm{Pencil} / \mathrm{NiO} /$ $\mathrm{Al}_{2} \mathrm{O}_{3}$ 表面光亮且外观均匀.

图2示出了上述6种材料的表面微观形貌. $\mathrm{Al}_{2} \mathrm{O}_{3}$ 基体 材料由不规则的陶瓷颗粒烧结而成. $\mathrm{NiO} / \mathrm{Al}_{2} \mathrm{O}_{3}$ 与 $\mathrm{Al}_{2} \mathrm{O}_{3}$ 基体表面显著不同, 出现了一层细小颗粒, 这显然是由于 $\mathrm{NiO}$ 的担载所致. 经铅笔涂层修饰之后, 所得Pencil/ $/ \mathrm{Al}_{2} \mathrm{O}_{3}$ 与 Pencil/ $/ \mathrm{NiO} / \mathrm{Al}_{2} \mathrm{O}_{3}$ 表面形貌几乎完全相同, 都变得更加 平滑. $\mathrm{Pd} / \mathrm{Pencil} / \mathrm{Al}_{2} \mathrm{O}_{3}$ 与 $\mathrm{Pd} / \mathrm{Pencil} / \mathrm{NiO} / \mathrm{Al}_{2} \mathrm{O}_{3}$ 膜的表面形 貌也几乎完全相同, 膜面均十分平整, 未见明显缺陷, 表 明 $\mathrm{NiO}$ 的担载对膜的制备没有显著影响. 两种钯膜的断 面微观结构如图3所示. 样品断面经打磨和抛光后, 钯金 属层变得极为光亮, 因此可通过光学显微镜清楚观察. $\mathrm{Pd} / \mathrm{Pencil} / \mathrm{Al}_{2} \mathrm{O}_{3}$ 与 $\mathrm{Pd} / \mathrm{Pencil} / \mathrm{NiO} / \mathrm{Al}_{2} \mathrm{O}_{3}$ 膜的断面形貌十分 相似, 钯金属层厚度均匀且与基体结合良好. 如前所述, 我们在制膜过程中通过改变镀液用量控制膜厚为 $5 \mu \mathrm{m}$, 而图3表明这与膜的实际厚度非常接近, 说明本工作所 采用的化学镀工艺能够充分转化镀液中的钯离子并沉 积成膜. 例如, 在每次更新镀液前均向镀液中添加了过 量联胺, 从而使镀液中残留的钯离子充分还原, 避免了 贵金属钯的损失.

\section{2. 膜的透氢性能}

钯膜的透氢性能采用 $\mathrm{H}_{2} / \mathrm{N}_{2}$ 单气体法测试 ${ }^{[14]}$, 温度为 350,400 和 $450^{\circ} \mathrm{C}$. 钯膜的透氢过程遵循溶解-扩散机制, 氢通量 $J$ 可用下式计算: $J=F\left(p_{\mathrm{r}}{ }^{n}-p_{\mathrm{p}}{ }^{n}\right)$. 式中, $F$ 为膜的渗 透率, $p_{\mathrm{r}}$ 和 $p_{\mathrm{p}}$ 分别为膜滞留侧和渗透侧的氢气压力, $n$ 为压 力指数, $0.5 \leq n \leq 1$. 通常, 氢在钯膜体相中的扩散为速率 控制步骤, 符合Sievert定律, 则 $n=0.5^{[16,17]}$.

测试结果如图4所示. 其中, 膜的选择性定义为同等 条件下氢气和氮气通量之比, 选择性越高则说明膜的缺 陷越少. 在测试条件下, $\mathrm{Pd} / \mathrm{Pencil} / \mathrm{NiO} / \mathrm{Al}_{2} \mathrm{O}_{3}$ 中的 $\mathrm{NiO}$ 将 被氢气还原, 从而原位得到 $\mathrm{Pd} / \mathrm{Pencil} / \mathrm{Ni} / \mathrm{Al}_{2} \mathrm{O}_{3}$ 膜.

我们前期研究发现, 铅笔修饰技术能有效避免基体 表面缺陷对制膜造成的不利影响, 即使在普通大孔基体 上也可以制得高选择性钯膜, 从而使钯膜的制备变得更 加容易 ${ }^{[12]}$. 但是由于本工作的初衷是为了研究镍催化剂 对膜泄漏CO的转化效果, 因此特意选择了一个 $\mathrm{H}_{2} / \mathrm{N}_{2}$ 选择 性较低、膜缺陷较多的Pd/Pencil/ $/ \mathrm{Ni}^{\prime} / \mathrm{Al}_{2} \mathrm{O}_{3}$ 膜进行透氢和催 化性能研究. 单气体渗透测试结果如图4所示. Pd/Pencil/ 
$\mathrm{Al}_{2} \mathrm{O}_{3}$ 和 $\mathrm{Pd} / \mathrm{Pencil} / \mathrm{Ni} / \mathrm{Al}_{2} \mathrm{O}_{3}$ 膜的 $\mathrm{H}_{2} / \mathrm{N}_{2}$ 选择性分别在 5000 以上和 1000 以下. 当压力指数 $n=0.5$ 时, 两膜的氢通量 与膜两侧氢气压力的关系曲线均呈良好的线性关系, 说 明氢原子体相扩散是速率控制步骤. 在 350, 400 和 $450{ }^{\circ} \mathrm{C}$ 下, $\mathrm{Pd} / \mathrm{Pencil} / \mathrm{Al}_{2} \mathrm{O}_{3}$ 膜的氢气渗透率 $F$ 分别为 110 , 126 和 $144 \mathrm{~m}^{3} /\left(\mathrm{m}^{2} \cdot \mathrm{h} \cdot \mathrm{MPa}^{0.5}\right)$, 而 $\mathrm{Pd} / \mathrm{Pencil} / \mathrm{Ni} / \mathrm{Al}_{2} \mathrm{O}_{3}$ 膜的氢 气渗透率 $F$ 分别为 120,133 和 $150 \mathrm{~m}^{3} /\left(\mathrm{m}^{2} \cdot \mathrm{h} \cdot \mathrm{MPa}^{0.5}\right)$. 可见, 在同样条件下两膜的氢气渗透率相近.

图4的结果表明 $\mathrm{Ni}$ 的担载对钯膜的氢渗透性能几乎 没有影响. 首先, 镍催化剂位于 $\mathrm{Al}_{2} \mathrm{O}_{3}$ 基体孔道内, 与钯膜 之间相隔一层石墨修饰材料, 不会污染钯膜或妨碍钯膜 的制备; 其次, 镍的担载量少, 并不会显著提高 $\mathrm{Al}_{2} \mathrm{O}_{3}$ 基体 的气体渗透阻力; 再次, 基体材料的氢气渗透阻力远小于 氢原子在金属钯体相中的扩散阻力, 氢原子体相扩散仍 是透氢速率控制步骤, 这也与图4的动力学分析结果相吻 合. 膜的氢通量与 $\mathrm{H}_{2} / \mathrm{N}_{2}$ 透氢选择性随温度的升高而升 高, 这是钯膜的典型特征. 氮气从钯膜缺陷处的泄漏方 式一般是Knudsen或Poiseuile扩散, $\mathrm{N}_{2}$ 通量分别与 $T^{-0.5}$ 或 $T^{-1}$ 成正比, 亦即随温度的升高而降低.

\section{3. 膜的氢分离与 $\mathrm{CO}$ 甲烷化性能}

在实际工作条件下, 原料氢中的杂质气体会降低钯 膜的透氢量 ${ }^{[18-20]}$. 除与压力、温度及原料气组成有关外, 钯膜的原料气处理能力和氢气产出量还与氢气回收率密 切相关. 当原料氢从钯膜滞留侧流过时, 随着氢气不断被 分离, 氢气浓度或氢分压不断下降, 钯膜的局部氢通量也 随之下降. 对任何一个特定的钯膜而言, 进料越快, 则原 料中的氢越来不及分离, 从而氢气回收率越低, 但钯膜滞 留侧的氢分压损失越小, 因而产氢量越高. 由此可见, 氢 气回收率越高则产氢量越低, 当钯膜滞留侧的尾气氢气 分压与渗透侧的氢气压力相等时, 氢气的回收率将达到 极限. 提高膜滞留侧压力和降低膜渗透侧压力是实现高 产氢量和高氢气回收率的有效手段.

本工作采用组成为 $\mathrm{H}_{2} 77.8 \%, \mathrm{CO} 5.2 \%, \mathrm{CO}_{2} 13.5 \%$ 和 $\mathrm{CH}_{4} 3.5 \%$ 的原料气, 测试了氢回收率为 $70 \%$ 时进料压 力与钯膜产氢量的关系, 结果如图5所示. 对比而言, $\mathrm{Pd} / \mathrm{Pencil} / \mathrm{Al}_{2} \mathrm{O}_{3}$ 和 $\mathrm{Pd} / \mathrm{Pencil} / \mathrm{Ni} / \mathrm{Al}_{2} \mathrm{O}_{3}$ 膜在同样温度和进 料压力下的产氢量并没有明显的差别. 例如, 在 350,400 和 $450{ }^{\circ} \mathrm{C}$ 下, $\mathrm{Pd} / \mathrm{Pencil} / \mathrm{Al}_{2} \mathrm{O}_{3}$ 膜在进料压力为 $0.25 \mathrm{MPa}$ 时 的产氢量分别为 $11.8,14.5$ 和 $17.0 \mathrm{~m}^{3} /\left(\mathrm{m}^{2} \cdot \mathrm{h}\right)$, 而 Pd/Pencil/ $\mathrm{Ni} / \mathrm{Al}_{2} \mathrm{O}_{3}$ 膜的相应产氢量分别为 $12.7,14.1$ 和 16.8 $\mathrm{m}^{3} /\left(\mathrm{m}^{2} \cdot \mathrm{h}\right)$.

钯膜的产氢纯度取决于原料氢浓度、膜的操作条件
和膜的完整性. 在膜的制备和长期运行过程中, 钯膜上会 出现针孔, 导致氢纯度下降. 本工作主要针对氢燃料电池 PEMFC对CO特别敏感的特点, 在 $\mathrm{Al}_{2} \mathrm{O}_{3}$ 基体材料孔道内 引入 $\mathrm{Ni}$ 催化剂, 从而可将膜泄漏的 $\mathrm{CO}$ 进行甲烷化. 在 $\mathrm{Ni}$ 催化剂的作用下, $\mathrm{CO}$ 和 $\mathrm{CO}_{2}$ 可与 $\mathrm{H}_{2}$ 发生如下反应:

$$
\begin{aligned}
\mathrm{CO}+3 \mathrm{H}_{2} & \rightarrow \mathrm{CH}_{4}+\mathrm{H}_{2} \mathrm{O} \\
\mathrm{CO}_{2}+4 \mathrm{H}_{2} & \rightarrow \mathrm{CH}_{4}+2 \mathrm{H}_{2} \mathrm{O}
\end{aligned}
$$

这样, $\mathrm{Pd} / \mathrm{Pencil} / \mathrm{Ni} / \mathrm{Al}_{2} \mathrm{O}_{3}$ 膜就同时具备了氢气分离和 $\mathrm{CO}$ 催化甲烷化两种功能, 其工作原理如图6所示. 尽管每 $1 \mathrm{~mol}$ 的 $\mathrm{CO}$ 和 $\mathrm{CO}_{2}$ 分别要消耗 3 和 $4 \mathrm{~mol}$ 氢气并产生 2 和 3 $\mathrm{mol}$ 的新杂质, 但少量的 $\mathrm{CH}_{4}$ 和 $\mathrm{H}_{2} \mathrm{O}$ 杂质对PEMFC没有毒 副作用. 由于钯膜泄漏的 $\mathrm{CO}$ 和 $\mathrm{CO}_{2}$ 浓度极低, 甲烷化过 程中所消耗的氢气完全可以忽略不计.

在进料压力 $0.25 \mathrm{MPa}$ 及氢回收率 $70 \%$ 的条件下, $\mathrm{Pd} / \mathrm{Pencil} / \mathrm{Al}_{2} \mathrm{O}_{3}$ 和 $\mathrm{Pd} / \mathrm{Pencil} / \mathrm{Ni} / \mathrm{Al}_{2} \mathrm{O}_{3}$ 膜产出氢中 $\mathrm{CO}, \mathrm{CO}_{2}$ 和 $\mathrm{CH}_{4}$ 的浓度见表1. 与原料气相比, $\mathrm{Pd} / \mathrm{Pencil} / \mathrm{Al}_{2} \mathrm{O}_{3}$ 膜产 出氢中 $\mathrm{CO}, \mathrm{CO}_{2}$ 和 $\mathrm{CH}_{4}$ 的浓度均下降了 3 个数量级, 证明 该膜具有良好的氢分离作用. 与 $\mathrm{Pd} / \mathrm{Pencil} / \mathrm{Al}_{2} \mathrm{O}_{3}$ 相比, $\mathrm{Pd} / \mathrm{Pencil} / \mathrm{Ni} / \mathrm{Al}_{2} \mathrm{O}_{3}$ 膜产出氢中 $\mathrm{CO}$ 和 $\mathrm{CO}_{2}$ 的浓度均至少低 了 1 个数量级, 但 $\mathrm{CH}_{4}$ 浓度却高了约 2 个数量级, 这显然是 $\mathrm{Pd} / \mathrm{Pencil} / \mathrm{Ni} / \mathrm{Al}_{2} \mathrm{O}_{3}$ 膜通过催化甲烷化所造成的. 一方面, 图4结果已表明, $\mathrm{Pd} / \mathrm{Pencil} / \mathrm{Ni} / \mathrm{Al}_{2} \mathrm{O}_{3}$ 膜比 $\mathrm{Pd} / \mathrm{Pencil} / \mathrm{Al}_{2} \mathrm{O}_{3}$ 膜 拥有更多缺陷, 但前者产出氢中 $\mathrm{CO}$ 和 $\mathrm{CO}_{2}$ 的浓度却显著 低于后者, 说明 $\mathrm{CO}$ 和 $\mathrm{CO}_{2}$ 已被额外转化或消除. 另一方 面, $\mathrm{Pd} / \mathrm{Pencil} / \mathrm{Al}_{2} \mathrm{O}_{3}$ 膜产出氢中CO, $\mathrm{CO}_{2}$ 和 $\mathrm{CH}_{4}$ 的浓度之比 与原料气较为相近, 但 $\mathrm{Pd} / \mathrm{Pencil} / \mathrm{Al}_{2} \mathrm{O}_{3}$ 膜产出氢中 $\mathrm{CH}_{4}$ 浓 度大大高于 $\mathrm{CO}$ 和 $\mathrm{CO}_{2}$, 说明 $\mathrm{Pd} / \mathrm{Pencil} / \mathrm{Ni} / \mathrm{Al}_{2} \mathrm{O}_{3}$ 膜具有良 好的甲烷化作用. 其产出氢中CO的浓度不超过 $0.0001 \%$, 完全能够满足PEMFC的要求. 表1的结果还表明, 随着温 度的升高, $\mathrm{Pd} / \mathrm{Pencil} / \mathrm{Al}_{2} \mathrm{O}_{3}$ 和 $\mathrm{Pd} / \mathrm{Pencil} / \mathrm{Ni} / \mathrm{Al}_{2} \mathrm{O}_{3}$ 膜产出氢 中 $\mathrm{CO}, \mathrm{CO}_{2}$ 和 $\mathrm{CH}_{4}$ 的浓度均呈下降趋势, 这与图4结果相 吻合, 亦即膜的透氢选择性随温度的升高而升高.

众所周知, 金属钯也是甲烷化催化剂 ${ }^{[21]}$, 但通常催化 剂中的钯金属颗粒直径都在纳米级, 而钯膜的表面积非 常小, 因此不会引起显著的甲烷化作用. 另外, 钯膜厚度 只有 $5 \mu \mathrm{m}$ 且钯金属只是分布在基体表面, 导致钯膜泄漏 的 $\mathrm{CO}$ 和 $\mathrm{CO}_{2}$ 与金属钯的接触时间极短,一般的钯膜(如 $\mathrm{Pd} / \mathrm{Pencil} / \mathrm{Al}_{2} \mathrm{O}_{3}$ ) 并不会产生明显的甲烷化作用, 因此 $\mathrm{Pd} / \mathrm{Pencil} / \mathrm{Ni} / \mathrm{Al}_{2} \mathrm{O}_{3}$ 膜的甲烷化功能显然只能归功于所引 入的镍催化剂. 这种双功能膜尤其适用于面向PEMFC 的氢气分离, 既有效解决了 PEMFC对氢燃料中CO格外 敏感的问题, 又提高了对钯膜缺陷的容忍度, 因而相当 
于延长了钯膜的使用寿命.

\section{4. 结论}

通过向多孔 $\mathrm{Al}_{2} \mathrm{O}_{3}$ 基体材料中引入镍催化剂, 成功 制备了同时具有氢分离和一氧化碳催化甲烷化功能的 钯复合膜 $\mathrm{Pd} / \mathrm{Pencil} / \mathrm{Ni} / \mathrm{Al}_{2} \mathrm{O}_{3}$, 既有效解决了质子交换膜 燃料电池(PEMFC) 对氢燃料中CO格外敏感的问题, 又 延长了钯膜的使用寿命, 而且由于钯膜所泄漏的 CO 和
$\mathrm{CO}_{2}$ 量极少, 甲烷化反应所消耗的氢气也可忽略不计. 因此, 这种双功能膜 $\mathrm{Pd} / \mathrm{Pencil} / \mathrm{Ni} / \mathrm{Al}_{2} \mathrm{O}_{3}$ 尤其适合于面向 PEMFC的氢分离用途. 本工作所提供的双功能膜制备 工艺中, 镍催化剂的引入对钯膜本身的制备和透氢性能 几乎没有影响, 铅笔涂层不仅起到修饰 $\mathrm{Al}_{2} \mathrm{O}_{3}$ 基体的作 用, 而且避免了镍催化剂与钯膜的直接接触. 未引入镍 催化剂的钯膜 $\mathrm{Pd} / \mathrm{Pencil} / \mathrm{Al}_{2} \mathrm{O}_{3}$ 对 CO甲烷化几乎没有催 化作用. 